10. Shara S. O. Profesiino-pedahohichna adaptatsiia molodykh vykladachiv vyshchykh navchalnykh zakladiv nepedahohichnoho profiliu, aref. na zdob. nauk. stupenia kand. ped. nauk spets: 13.00.04 / Shara Svitlana Oleksiivna. - Pereiaslav-Khmelnytskyi - 2013. - $21 \mathrm{~s}$.

11. KrólR. Duchowość nauczycielaakademickiego. PedagogikaKatolicka№ 2(1/2008) styczen-czerwiec. - S.200-207.

12. Zimny J. Samoksztalceniepedagogówdrogąkuefektywnościpracy opiekuńczo-wychowawczej PedagogikaKatolickaNr 17(2/2015) lipiec-grudzien. s. 16-32.

Одержано статтю: 3.11 .2018

Прийнято до друку: 2.12.2018

УДК $371.134: 372.461: 371.15$

DOI:10.15330/esu.14.88-96

\section{Олександра Кузенко,}

кандидат педагогічних наук, доцент,

ДВНЗ “Івано-Франківський національний

медичний університет"

(м. Івано-Франківськ, Україна)

Olexandra Kuzenko,

Candidate of pedagogical sciences,

Associate Professor, Ivano-Frankivsk National Medical

University (Ivano-Frankivsk, Ukraine)

oleksandrakuz@ukr.net

\title{
ФОРМУВАННЯ ФАХОВОЇ КОМПЕТЕНТНОСТІ МАЙБУТНІХ УЧИТЕЛІВ- ЛОГОПЕДІВ В ПРОЦЕСІ ПРОФЕСІЙНОЇ ПІДГОТОВКИ
}

\section{FORMING OF PROFESSIONAL COMPETENCE OF FUTURE TEACHERS-SPEECH THERAPISTS IN PROFESSIONAL TRAINING PROCESS}

Стаття присвячена аналізу актуальних проблем формування фахової компетентності майбутніх учителів-логопедів в прочесі професійної підготовки. Професійна підготовка майбутніх учителів-логопедів розглядається як иілеспрямований керований прочес, який забезпечуе формування професійної компетентності та особистісно значуиих якостей, необхідни для здійснення логопедичної діяльності. Завдяки кожному структурному елементу професійної підготовки майбутніх логопедів до професійнопедагогічної діяльності, важливе місче серед яких палежить мотивачійно-иільовому, змістовому, операційному та результативно-очіночному компонентам відбувається забезпечення педагогічних умов для формування їх професійної компетентності.

Акцентується, що актуальною проблемою сучасної вищої освіти фахівців у галузі організаиії професійної підготовки учителів-логопедів є необхідність переосмислення підходу до освітньої діяльності студентів, відмова від морально застарілої дидактичной моделі й переходу на позичії гуманістичної освітньої парадигми зі студенточентрованим підходом. ЦЦе зумовлюс необхідність створения педагогічних умов для отримання освіти, на основі крацих досягнень національної освіти та європейських традиій, формування в студентів особистісних якостей, загальнокультуриих $і$ професійних компетенцій відповідно до вимог напряму підготовки "Корекиійна освіта" та спечіалізації "Логопедія: рання діагностика і корекція".

Метою навчального прочесу закладів вицої освіти в статті визначасться підготовка кваліфікованих випускників, ио: володіють новітніми технологіями, здатних здійснювати професійно абілітаційну, превентивну діяльність стосовно дітей раннього віку, надати диферениійовану допомогу дітям доикільного віку з розвитку, навчання $i$ виховання мовлення, активізувати їх потенціал, на демократичних та гуманістичних засадах реалізовувати освітню політику як пріоритетну функиію держави, шо спрямовується на розвиток та самореалізацію особистості, задоволення ї освітніх $i$ 
духовно-культурних потреб на базі установ освіти, сочіальної сфери й охорони здоров'я, а також бути конкурентоспроможними на ринку прачі

Ключові слова: професійна підготовка, фахова компетентність, студентоиентрований підхід, учителі-логопеди.

The article is devoted to the analysis of topical problems of forming professional competence of future teachers-speech therapists in the process of professional training. Professional training of future teachers-speech therapists is considered as a purposeful controlled process, which ensures the forming of professional competence and personally significant qualities necessary for the implementation of speech therapist activity. Thanks to each structural element of the professional training of future speech therapists for vocational and pedagogical activities, an important place among which belongs to the motivative-target, content, operational and performance-assessment components happens providing of pedagogical conditions for the forming of their professional competence.

It is emphasized that the current problem of modern higher education of specialists in the field of professional training of teachers-speech therapists is the need to rethink the approach to educational activities of students, the rejection of the morally outdated didactic model and the transition to the position of a humanistic educational paradigm with a student-centered approach. This necessitates the creation of pedagogical conditions for receiving the education, based on the best achievements of national education and European traditions, the forming of students' personal qualities, general cultural and professional competences in accordance with the requirements of the direction of training "Corrective education" and the specialization "Speech therapy: early diagnostics and correction".

The purpose of the educational process of institutions of higher education in the article is determined the training of qualified graduates who: have the latest technology capable of carrying out vocational and preventive activities with children of early age, provide differentiated assistance to preschool children for the development, education and upbringing of speech, to increase their potential, on democratic and humanistic principles to implement educational policy as a priority function of the state, which is aimed at the development and self-realization of the personality, satisfaction of its educational and spiritual and cultural needs on the basis of institutions of education, social sphere and health care, as well as being competitive on the labor market.

Key words: professional training, professional competence, student-centered approach, teachers-speech therapists.

Постановка проблеми. Професійна підготовка майбутніх учителів-логопедів як полівекторний процес, спрямований на оволодіння знаннями різних галузей науки, важливе місце серед яких належить педагогіці, психології, лінгвістиці, дефектології, медицині. Його метою правомірно визначено професійну підготовку майбутнього логопеда, зацікавленого професійною діяльністю, здатного забезпечити організаційну, змістову, методичну складову логопедичної складової освітнього простору навчальної інституції, а також координувати взаємодію дорослих щодо максимального розвитку дітей, діагностувати і долати мовленнсві порушення та здійснювати їх профілактику, проводити просвітницьку роботу [3].

На думку фахівців у галузі організації професійної підготовки учителівлогопедів, актуальною проблемою сучасної вищої освіти $\epsilon$ необхідність переосмислення підходу до освітньої діяльності студентів, відмова від морально застарілої дидактичної моделі й переходу на позиції гуманістичної освітньої парадигми зі студентоцентрованим підходом. Це зумовлює необхідність створення педагогічних умов для отримання освіти, на основі кращих досягнень національної освіти та європейських традицій, формування в студентів особистісних якостей, 
загальнокультурних і професійних компетенцій відповідно до вимог напряму підготовки "Корекційна освіта" та спеціалізації “Логопедія: рання діагностика i корекція".

Відповідно, метою навчального процесу закладів вищої освіти має стати підготовка кваліфікованих випускників, що: володіють новітніми технологіями, здатних здійснювати професійно абілітаційну, превентивну діяльність стосовно дітей раннього віку, надати диференційовану допомогу дітям дошкільного віку 3 розвитку, навчання i виховання мовлення, активізувати їх потенціал, на демократичних та гуманістичних засадах реалізовувати освітню політику як пріоритетну функцію держави, що спрямовується на розвиток та самореалізацію особистості, задоволення iіi освітніх і духовно-культурних потреб на базі установ освіти, соціальної сфери й охорони здоров'я, а також бути конкурентоспроможними на ринку праці [6, с. 287].

Аналіз актуальних досліджень. Основними напрямками аналізу проблеми професійної підготовки в сучасних наукових дослідженнях стали: визначення шляхів удосконалення навчально-виховного процесу у закладах вищої освіти (А. Алексюк, В. Безпалько, С. Гончаренко, М. Євтух, Н. Кузьміна, В. Лозова, Н. Тализіна, М.Ярмаченко та інші); педагогічні умови формування професійної компетентності майбутніх учителів (О. Абдуліна, С. Архангельський, Е. Белозерцев, 3. Васильєва, О. Дубинчук, В. Свдокимов, А. Кірсанов, І. Прокопенко, В. Сластьонін, М. Шкіль та інші); визначення основних компонентів системи підготовки дефектологів (В. Бондар, Г. Живіна, І. Колісник, Н. Назарова, С. Миронова, В. Синьов, В. Тарасун, Л. Федорович, О. Шевченко, М. Шеремет та інші).

Результати досліджень Є. Голанта, В. Гузєєва, О. Іонової, Б. Єсіпова, I. Лернер, М. Скаткіна, М. Сорокіна, Т. Хлєбнікової дозволяють стверджувати, що професійно-педагогічна підготовка логопедів покликана забезпечити формування в майбутніх вчителів системних знань та педагогічних умінь, професійної позиції, готовності до інноваційної діяльності, готовності до безперервного збагачення професійних можливостей та особистісних якостей.

Таким чином, аналіз наукових досліджень дозволяє визначити сутність різних підходів до визначення змісту, мети і завдань професійної діяльності вчителялогопеда, що, в свою чергу, дозволяє окреслити напрями його професійної підготовки.

Мета статті - розкрити особливості формування фахової компетентності майбутніх учителів-логопедів в процесі їх професійної підготовки.

Виклад основного матеріалу. Закономірно, що результатом підготовки студентів до професійної діяльності визначається певний рівень готовності або підготовленості. Вцілому “готовність до професійної діяльності вчителя” в фахових дослідження розглядаємо як: інтегративну якість особистості, структурними елментами якої $є$ позитивне ставлення до професії, здібності, знання, уміння, навички, стійкі професійно важливі якості; актуальний психічний стан, що $\epsilon$ результатом педагогічної діяльності; складне утворення, в центрі якого знаходиться ставлення до педагогічної діяльності, як до головного сенсу життя, відповідальне ставлення до цієї діяльності, здатність до самовіддачі в педагогічній діяльності, професійні якості, знання, вміння, навички тощо [2].

Необхідно зауважити, що сутність поняття “підготовленість", в свою чергу, відображає “наявність підготовки до будь-якої справи, роботи” [4]. Відповідно 
підготовленість студента до логопедичної діяльності передбачає наявність у нього спеціальних знань, умінь, навичок, необхідних для здійснення цієї діяльності.

На думку Л. Федорович, “професійна діяльність логопеда полягає у здійсненні профілактичного, діагностичного та корекційного логопедичного впливу на осіб із порушеннями мовлення первинного та вторинного характеру, що забезпечується системою логопедичної роботи як комплексом занять із запобігання, виявлення й усунення порушень усного і писемного мовлення з раннього віку" [7, с. 9].

3 огляду на це, розкриваючи сутність професійно-педагогічної підготовки вчителя-логопеда можна розглядати як “процес професійного становлення особистості, що передбачає використання сукупності прийомів соціального впливу на особистість студента, залучення його до різних видів навчальної і позанавчальної діяльності з метою набуття системи професійно важливих якостей, необхідних для роботи 3 особами 3 порушеннями мовлення, системного освоєння основ логопедичного знання та формування професійної готовності вчителя-логопеда, який має практичні вміння навчати, виховувати, діагностувати й корегувати мовлення дітей, підлітків і дорослих" [3, с. 175].

Аналіз наукових праць Є. Богданова, П. Гальперіна, М. Дяченко, Л. Кандибович, Н. Кузьміної, В. Сластьоніна доводить, що професійно-педагогічна підготовка вчителя в закладі вищої освіти педагогічного профілю є складною, багатоаспектною, багатофункціональною діяльністю. Структура професійної підготовки складається 3 мети, змісту, операцій, результату і відповідних компонентів: мотиваційноцільового, змістового, операційного та результативно-оціночного.

Необхідно відзначити, цільовий компонент $є$ важливою складовою підготовки майбутнього вчителя, оскільки, як зауважує Ю. Пінчук, “мета професійної підготовки майбутнього вчителя-логопеда полягає в тому, щоб підготувати фахівця, який має зацікавленість та позитивне ставлення до логопедичної діяльності, здатний забезпечити організаційну, змістову, методичну складову логопедичного сегменту в єдиному освітньому просторі навчального закладу, об'єднувати зусилля та взаємодію дорослих щодо максимального розвитку дітей, діагностувати і долати мовленнєві порушення та здійснювати їх профілактику, проводити просвітницьку роботу" [5, с. 142].

Змістовий компонент підготовки вчителя-логопеда. в свою чергу, включає в себе сукупність професійних знань, умінь та навичок як загальних, так і спеціальних. Серед спеціальних дисциплін провідне місце належить курсу “Логопедія”, вивчення якого передбачає тісний взаємозв'язок фундаментальних i професійних знань, їх глибоке засвоєння забезпечує розуміння сучасного стану теорії і практики логопедії як конкретної науки та оволодіння технологіями ранньої диференціальної діагностики окремих розладів мовлення, здійснення системного підходу до аналізу, подолання і попередження мовленнєвих порушень.

Зважаючи на те, що майбутньому вчителю-логопеду в процесі навчання важливо оволодіти спеціальними та загальнопедагогічними уміннями, фахівці обстоюють необхідність певних змін у змістовому компоненті їх професійної підготовки. Серед рекомендацій, висловлених Сінопальніковою Н.М., обстоюється необхідність:

- інтеграції змісту навчальних психолого-педагогічних дисциплін 3 метою підвищення готовність студентів до організації та проведення логопедичної, виховної роботи 3 дітьми 3 мовленнєвими порушеннями;

- доповнення варіативної компоненти освітньо-професійної програми підготовки фахівців питаннями 3 оволодіння діагностичними та корекційними методиками; 
- оновлення змісту практичної підготовки студентів 3 урахуванням сучасних вимог до логопедичної допомоги [3, с. 177].

Дослідники зауважують, що операційний компонент підготовки майбутнього вчителя-логопеда у закладах вищої освіти представлений традиційними для цієї ланки освіти методами, формами та засобами навчання. До основних форм організації навчального процесу у вищих навчальних закладах належать лекційні, семінарські, лабораторні і практичні заняття, а також самостійна робота студентів. Також відбувається поступове впровадження таких нетрадиційних форм як лекція пресконференція, семінар - “мозковий штурм”, семінар - “круглий стіл”, семінар ділова гра тощо.

Відтак, учені С. Шаховська та Л. Федорович вважають, що найпоширеніші методи навчання майбутніх учителів-логопедів можна класифікуваи в дві основі групи групи:

- інформаційно-розвивальні (лекція, розповідь, пояснення, бесіда, демонстрація навчального кінофільму, самостійна робота з книгою та інше);

- проблемно-пошукові (проблемна лекція, евристична бесіда, навчальна дискусія, пошукова лабораторна робота), методи практичного навчання (аналіз педагогічних ситуацій, розв'язання педагогічних задач, ділова гра та інше).

Педагоги констатують, що останнім часом особливого значення в підготовці логопедів набуває самостійна та науково-дослідна робота. Індивідуально-дослідницька робота 3 курсу "Логопедія" - це моделі логодидактичних експериментів. Прикладом такої роботи $є$ індивідуальне навчально-дослідне завдання (IHД3), яке містить результати дослідницького пошуку, висвітлює рівень опанування знаннями 3 логопедії та практичними уміннями аналізувати досліджувану проблему віддзеркалює певний рівень готовності студентів до логопедичної діяльності [8, с. 7].

Результати дослідження О. Іонової доводять, що ефективність підготовки майбутніх учителів і вчителів-логопедів, зокрема, залежить від набуття ними досвіду проведення логопедичної роботи. На думку, вченої, важливою формою набуття досвіду $є$ логопедична практика (навчальна та виробнича), під час яких студенти ознайомлюються 3 діяльністю логопеда, навчаються планувати логопедичну роботу, аналізувати результати проведеного логопедичного обстеження, прогнозувати динаміку мовленнєвого розладу, вести мовленнєву карту, здійснювати консультативну допомогу батькам дітей із порушеннями мовлення тощо. Виробнича практика полягає в проведенні різних видів логопедичних занять (індивідуальних, підгрупових, групових, фронтальних) у дошкільних навчальних закладах, дитячих поліклініках та на шкільних логопунктах [1, с. 37].

Необхідно зазначити, що результативний компонент професійно-педагогічної підготовки майбутніх учителів-логопедів відображає рівень досягнення випускником професійної компетентності - інтегративної якості особистості, яка виявляється в готовності максимально ефективно здійснювати діагностику, корекційнопревентивне навчання та особистісний розвиток дітей з вадами мовлення.

Отож професійна підготовка вчителя-логопеда у закладі вищої освіти $\epsilon$ інтегрованим освітнім процесом, в якому поєднуються відносно самостійні, але взаємозалежні і взаємообумовлені види підготовки: методологічна, культурологічна, методична, психологопедагогічна, спеціальна, дидактична, професійно-етична та практична.

Методологічна підготовка забезпечує формування в студентів системи знань про принципи, методи дослідження та перетворення педагогічної діяльності, що 
дозволить у подальшому розробляти оптимальну педагогічну стратегію, проектувати шляхи навчання та виховання кожної дитини з мовленнєвими вадами. За допомогою методичної підготовки студенти опановують знання про принципів, зміст, правила, засоби, активні методи та форми сучасної діагностики, корекційного навчання. Таким чином у майбутніх фахівців формується готовність до здійснення логопедичної роботи в навчальних закладах.

Культурологічна підготовка, в свою чергу, спрямована на забезпечення педагогічних умов для розвитку світогляду вчителя-логопеда, розширення його загальної освіти.

Важливим напрямом професійної підготовки майбутніх логопедів правомірно вважається психолого-педагогічна підготовка. Вона спрямована на професійну освіту вчителя-логопеда, формування і розвиток педагогічних умінь, розвиток його творчої індивідуальності.

Дидактична підготовка дозволить майбутнім логопедам проводити навчальновиховну, корекційну роботу з дітьми, що мають мовленнєві вади, забезпечувати сприятливі умови для продуктивного засвоєння ними відповідних спеціальних програм з урахуванням виду мовленнєвого порушення вікових, індивідуальних психофізичних особливостей дітей

Доцільно зауважити, що спеціальна підготовка як частина професійної підготовки забезпечує оволодіння теоретичними i практичними знаннями, необхідними для логопеда.

У процесі професійно-етичної підготовки майбутній логопед навчається використовувати у своїй роботі принципи педагогічної етики, поважати дитячу гідність, захищати дитину від будь-яких форм фізичного або психічного насильства. Метою практичної підготовки $є$ формування системи вмінь $\mathrm{i}$ навичок, розвиток здібностей та набуття професійного досвіду логопедичної діяльності. Інтеграція усіх видів підготовки майбутніх вчителів-логопедів дасть можливість значно підвищити їх готовність до професійної діяльності [3, с. 177-179].

Необхідно зауважити, що із приєднанням української освіти до Болонського процесу i розробкою Державного галузевого стандарту "Корекційна освіта" формування компетентності майбутніх логопедів у процесі професійної підготовки базується на:

1) компетентнісному підході, що визначається новою концепцією освіти, відповідно до неї складником державних освітніх стандартів є предметні компетенції фахівця (Н. Бібік, В. Буряк, І. Малафіїк, О. Пометун, О. Савченко, В. Якунін та ін.);

2) соціокультурному підході, який полягає в тому, що освітнє середовище розглядається як соціокультурне середовище (І. Бех, В. Кремень та ін.);

3) системному підході, з позицій якого здійснюється професійна підготовка майбутніх логопедів як складна, соціальна, динамічна, самоорганізована система, у межах якої системоутворювальні елементи вступають у специфічні навчальнопрофесійні відносини (В. Афанасьєв, В. Загвязинський, І. Зязюн);

4) особистісно орієнтованому підході, який базується на суб'єктному підході до діяльності індивіда (Б. Ананьєв, І. Бех, Л. Виготський, І. Зимня);

5) діяльнісному підході, який теоретично обгрунтували (Г. Атанов, Г. Балл, Л. Виготський, О. Леонтьєв, С. Рубінштейн, В. Семиченко), згідно з яким розвиток особистості здійснюється під час діяльності, в якій вона бере участь;

6) соціально-педагогічному підході (М. Євтух, I. Зверєва та ін.), який репрезентує сучасний соціум, як багатогранну систему, що є умовою успішного 
розвитку й у якому працюватиме професійно-компетентний і особистісно зрілий логопед;

7) технологічному підході (І. Звєрєва, І. Зимня, С. Сисоєва та ін.), який передбачає гнучке інструментальне управління навчальним процесом, охоплюючи низку напрямів у дидактиці вищої школи: діалогове, контекстне навчання, проблемномодульне й рейтингово-модульне навчання, імітаційне та ігрове моделювання [6, c. 288].

У контексті оновлення якості якості підготовки логопеда в сучасній теорії та практиці професійної підготовки фахівців визначено наступні принципи організації формування їх фахової компетентності:

принцип гуманістичних цінностей та реалізації прав людини, сутність якого відображає цінність кожної особистості, рівність прав та можливостей, надання підтримки незалежно від психофізичного, соціального статусу, релігійних переконань, етнічної належності, місця проживання. Це, зумовлює необхідність урахування соціо-політичних, соціо-культурних, психолого-педагогічних умов життедіяльності суспільства, що впливають на структуру і зміст професійної підготовки вчителя, в цілому, та становлення системи професійної підготовки майбутнього учителя- логопеда.

Наступним важливим принципом $є$ демократичність професійної підготовки майбутніх логопедів, який полягає в створенні рівних, однаково сприятливих для всіх студентів, можливостей для засвоєння змісту навчальних дисциплін та прояву власних здібностей і власної творчої індивідуальності у близькому для себе виді діяльності, відкриття широких можливостей для його самореалізації.

Для принципу особистісної зоріснтованості професійної підготовки майбутніх логопедів як системи розвитку їхньої індивідуальності, характерна перевага в педагогічному процесі розвитку особистісних якостей: “здатність учитися; глобальне мислення; функціональна грамотність; культура людського спілкування; професійна універсальність та гнучкість; професійність як інтеграція загальної освіченості та грунтовних і широких спеціальних навичок і умінь; здатність застосовувати знання в конкретних ситуаціях; самостійність і критичність мислення; відповідальність, дисциплінованість, акуратність, прихильність до праці; підготовленість до невідомого майбутнього; вміння пристосовуватися до змін".

Розробка теоретико-методологічних основ професійної підготовки логопедів до роботи з дітьми різних вікових категорій із різними формами порушень мовлення, програмно-методичного інструментарію, аналіз і моніторинг результатів впровадження організаційної моделі освіти, оцінка ефективності технологій, що використовуються для досягнення результату в професійній діяльності, проведення незалежної експертизи забезпечується завдяки дотриманню принципу науковості.

Дотримання принщипу системного підходу до організації та реалізації навчально-виховного процесу підготовки логопедів до роботи 3 дітьми ранньго віку 3 ризиком виникнення порушень мовлення забезпечує ефективність фахової підготовки в закладах вищої освіти.

Принцип інтегративності видів знань (психологічних, педагогічних, медичних тощо) передбачає врахування методологічного знання про професійну підготовку майбутнього логопеда, що передбачає загальнофілософські, загальнонаукові та частково специфічні аспекти.

Принцип урахування когнітивних стилів студентів передбачає опору на їх пізнавальний інтерес, спільний творчий пошук педагога i студентів, активізацію 
учасників навчального процесу й реалізацію процесу розвитку професійної індивідуальності суб'єктів.

Принцип контекстного навчання, що уможливлює зв'язок і наступність професійної підготовки із професійно-педагогічною діяльністю, життям та педагогічною практикою. Принцип міжвідомчої інтеграції та соціального партнерства, що сприяє координації дій різних відомств, соціальних інститутів, служб з метою оптимізації процесу освітньої інтеграції осіб з порушеннями мовлення [6, с. 288-289].

Висновки. Таким чином, проведений аналіз свідчить про те, що професійнопедагогічна підготовка вчителя-логопеда - це цілеспрямований керований процес, який забезпечує формування професійної компетентності та особистісно значущих якостей, необхідних для здійснення логопедичної діяльності. Завдяки кожному структурному елементу професійної підготовки майбутніх логопедів до професійнопедагогічної діяльності, важливе місце серед яких належить мотиваційно-цільовому, змістовому, операційному та результативно-оціночному компонентам відбувається забезпечення педагогічних умов для формування їх професійної компетентності.

\section{Література}

1. Іонова О. М. Теоретичні питання підготовки майбутніх учителів до застосування інтегрованих форм організації навчального процесу початкової школи / О. М. Іонова, Н. М. Сінопальнікова // Вісник Дніпропетровського університету імені Альфреда Нобеля. Серія "Педагогіка і психологія". Педагогічні науки. 2013. № 2 (6). С. 35-39.

2. Мижериков В. А Введение в педагогическую профессию / В. А. Мижериков, М. Н. Ермоленко. Москва : Педагогическое общество России, 1999. 288 с.

3. Сінопальнікова Н. М. Підготовка майбутніх учителів-логопедів до професійної діяльності // Засоби навчальної та науково-дослідної роботи. Вип. 43. 2014. С. 173-182.

4. Словник психолого-педагогічних понять і термінів [Електронний ресурс]. Режим доступу : http://osvita.ua/school/psychology/1270/.

5. Пінчук Ю. В. Готовність студентів-логопедів до професійної діяльності // Дефектологія. 2004. №3. C. 41-44.

6. Федорович Л.О. Концептуальні засади підготовки логопеда до роботи з дітьми раннього віку у вищих навчальних закладах в умовах інтеграції в європейський освітній простір // Науковий часопис. Корекційна педагогіка. № 12. 2012.С. 286-290.

7. Федорович Л. О. Теорія і практика підготовки майбутніх педагогів логопедів у вищих навчальних закладах / Л. О. Федорович // Імідж сучасного педагога. 2005. № 6-7. С. 7-11.

8. Шаховская С. Н. Современные тенденции в вузовской подготовке логопедов / С. Н. Шаховская // Логопед в детском саду. 2007. № 8 (23). С. 5-9.

\section{References}

1. Ionova O. M. Teoretychni pytannia pidhotovky maibutnikh uchyteliv do zastosuvannia intehrovanykh form orhanizatsii navchalnoho protsesu pochatkovoi shkoly / O. M. Ionova, N. M. Sinopalnikova // Visnyk Dnipropetrovskoho universytetu imeni Alfreda Nobelia. Seriia "Pedahohika i psykholohiia”. Pedahohichni nauky. 2013. № 2 (6). S. 35-39.

2. Myzherykov V. A Vvedenye v pedahohycheskuiu professyiu / V. A. Myzherykov, M. N. Ermolenko. Moskva : Pedahohycheskoe obshchestvo Rossyy, 1999. $288 \mathrm{~s}$.

3. Sinopalnikova N. M. Pidhotovka maibutnikh uchyteliv-lohopediv do profesiinoi diialnosti // Zasoby navchalnoi ta naukovo-doslidnoi roboty. Vyp. 43. 2014. S. 173-182.

4. Slovnyk psykholoho-pedahohichnykh poniat i terminiv [Elektronnyi resurs]. Rezhym dostupu http://osvita.ua/school/psychology/1270/.

5. Pinchuk Yu. V. Hotovnist studentiv-lohopediv do profesiinoi diialnosti // Defektolohiia. 2004. №3. S. 41-44.

6. Fedorovych L.O. Kontseptualni zasady pidhotovky lohopeda do roboty z ditmy rannoho viku u vyshchykh navchalnykh zakladakh $v$ umovakh intehratsii v yevropeiskyi osvitnii prostir // Naukovyi chasopys. Korektsiina pedahohika. № 12. 2012.S. 286-290.

7. Fedorovych L. O. Teoriia i praktyka pidhotovky maibutnikh pedahohiv lohopediv u vyshchykh navchalnykh zakladakh / L. O. Fedorovych // Imidzh suchasnoho pedahoha. 2005. № 6-7. S. 7-11. 
8. Shakhovskaia S. N. Sovremennye tendentsyy v vuzovskoi podhotovke lohopedov/ S. N. Shakhovskaia // Lohoped v detskom sadu. 2007. № 8 (23). S. 5-9.

Одержано статтю: 8.11.2018

Прийнято до друку: 3.12 .2018

УДК 378.015.31.041:37.011.3-052

DOI: $10.15330 /$ esu. $14.96-101$

\author{
Юлія Ненько, \\ доктор педагогічних наук, доцент, \\ Черкаський інститут пожежної безпеки імені \\ Героїв Чорнобиля НУЦЗУ (м. Черкаси, Україна) \\ Yuliya Nenko, \\ Doctor of pedagogical sciences, Associate Professor, \\ Cherkasy institute fire safety named after Heroes of \\ Chernobyl NUTZU (Cherkasy, Ukraine) \\ julial8016@ukr.net
}

\title{
ПРОФЕСІЙНИЙ САМОРОЗВИТОК ПЕДАГОГА: СВІТОВІ ТЕНДЕНЦЇ̈
}

\section{PROFESSIONAL SELF-DEVELOPMENT OF A TEACHER: GLOBAL TRENDS}

\begin{abstract}
Проаналізовано сучасний стан проблеми професійного розвитку педагогічних прачівників, виявлено світові тендениії та закономірності досліджуваного явица. Здійснено порівняльний аналіз результатів опитування понад 70000 освітян із 23 крайнучасниць щодо їхнього професійного саморозвитку. Встановлено, що інтенсивність, тривалість та форми професійного саморозвитку як активної специфічної діяльності педагога залежать від його особистості. Доведено, ио місие розтаиування закладу освіти, форма власності не виливають на перебіг цього прочесу.
\end{abstract}

Ключові слова: вчитель, саморозвиток, професійний саморозвиток.

The author analyzed the present state of the problem of professional development of pedagogical workers, the world tendencies and normality of the investigated phenomenon are revealed. The investigation proves that modern education systems seek to provide teachers with opportunities for professional self-development to maintain a high standard of teaching and to retain a high-quality teacher workforce. A comparative analysis of the survey results of over 70,000 educators from 23 participating countries regarding their professional development has been carried out. The study proves that effective professional development of a teacher is on-going process, includes training, practice and feedback, and demands adequate time and support of the head of the educational institution. It has been established that the intensity, duration and forms of professional self-development as an active specific activity of the teacher depend on his/her personality. It is proved that the location of the institution of education, the form of ownership does not affect the course of this process. The study recognises that professional self-development of a teacher can be provided in many ways, ranging from the formal to the informal; in the form of courses, workshops or formal qualification programmes, collaboration between educational institutions or teachers across the country.

Key words: teacher; self-development; professional self-development.

Актуальність. Модернізація сучасного освітнього простору, реформування галузі змінюють роль та функції як початкової, середньої, так і вищої школи, водночас змінюються і вимоги, що висуваються до педагогічних працівників. Так, сучасний освітянин повинен вміти працювати у багатокультурному класі; приділяти увагу інтеграції учнів/здобувачів із особливими потребами; ефективніше використовувати інформаційні та комунікаційні технології для навчання тощо. 